\title{
Competitiveness Assessment for Transport Enterprises in the Context of Accelerated Development of the International Logistics Infrastructure
}

\author{
Olga Ievsieieva ${ }^{1}$ \\ ${ }^{1}$ Ukrainian State University of Railway Transport, Feierbakh Square 7, 61050, Kharkiv, Ukraine
}

\begin{abstract}
In the study, the authors have identified the dominant trends in the development of the international road transport services market. These include monopolization and protectionism, structural imbalances, namely, predominance of European transport companies in the international motor transport market, prevailing of private transport companies. Hence, the researchers determined the general vector of improvement of the motor transport services market in the modern stage of internationalization of global economic relations. The current trends in the development of the international road transport services market in Ukraine are substantiated. The authors propose a competitiveness assessment methodology for transport enterprises. It is proposed to quantify the following elements as part of the competitiveness coefficient of a transport enterprise: 1) the range of offered transportation services; 2) pricing policy; 3) advertising; 4) public relations; 5) sales system; 6) employee incentive system; 7) innovative activity of the enterprise. Using the proposed methodological approach will help making reasonable management decisions to improve the efficiency of transport enterprises, to expand the information base of economic research, and to improve the quality of analysis in the context of accelerated development of the international logistics infrastructure.
\end{abstract}

Searching for a solution of the problem how to increase the competitiveness of enterprises in the context of the development of the international logistics infrastructure is becoming increasingly important in view of the globalization of the world economy, transformation of the economic environment, and the growing needs of people and businesses in transport services. The competitiveness level is based on the assessment of the enterprise, which shows how successful this enterprise is in the market and how effective its activity is.

The transport system is one of the most significant components of the global infrastructure and economic environment of Ukraine. The transport system creates conditions for transportation of goods and services, as well as the mobility of the population and production factors, and thus serves as a link in the global economy, ensuring its integrity and unity. It was the development of the transport infrastructure that served as the initial prerequisite for the formation of a global economy. Today, the Ukrainian transport

${ }^{1}$ Corresponding author: polkya@meta.ua 
infrastructure retains this function, allowing it to take advantage of the international division of labor, enhancing the internationalization of world economic relations.

The increasing degree of integration occurring within the world economic space in recent years confirms the imperative of the development of the Ukrainian transport infrastructure in order to ensure the effective functioning of these integration associations, mainly focused on the development of trade and transport enterprises. In this context, the modern international transport infrastructure of Ukraine needs objective analysis and evaluation for the needs determined by the imperatives of global development. The competitive analysis of Ukrainian transport companies is of paramount importance, since it would allow identifying the direction of their modernization and improving the competitiveness of enterprises.

In the study, we have identified dominant trends in the development of the international road transport services market (monopolization and protectionism; structural imbalances, namely, predominance of European transport companies in the international motor transport market; predominance of private transport companies), which allowed us to determine the general vector of its improvement in the current stage of internationalization of global economic relations.

The current trends in the development of the international transport infrastructure include the globalization of logistics, prevalence of non-monetary factors in the development of international transport infrastructure to increase the investment attractiveness of the international transport infrastructure. In our opinion, now when the global competition is formed in the world market of services of transport infrastructure enterprises, price competition is becoming an increasingly relevant area. Therefore, the systems of integrated logistics and intermodal transport technologies are sustainably developing, since they allow optimal combination of various types of transport.

Today, transport companies seek to minimize their risks and costs. Therefore, integrated associations of transport companies from different countries are becoming ever popular. The efficiency of transport services is increased with the integration. The integrated transportation scheme involves concluding an agreement with a major international transport company, which plots and organizes the optimal transportation route and concludes further transportation agreements with forwarding companies operating in the countries which the customer's freight is transported through.

The main problems in the development of international transport infrastructure include the lack of unified standards of the international customs system, poor accessibility of transport infrastructure, uneven involvement of various types of transport in the transport infrastructure, the problem of security and attraction of investments to upgrade the transport industry, the problem of developing regulatory support for the improvement of the transport system and transport services market, shortage of qualified professionals, territorial and structural inconsistencies in the operation of transport infrastructure, insufficient labor mobility in the transport infrastructure, poor quality of transport services, increased adverse impact of vehicle operation on the environment, insufficient use of integrated logistics systems, poor development of the intermodal transport technology, and low usage of information systems.

The conducted analysis revealed that the swift increase in demand for international motor transportation and the development of modern trade leads to a qualitative change in the international road transport services market associated with increased competition: the position of European transport companies has improved in recent years; in 2012, Western European countries controlled more than $20 \%$ of the market under investigation. Therefore, we concluded about a tendency of forming the so-called "European monopoly on international road transport". 
In the course of the research, we revealed that the current directions of the development of the international road transport services market in Ukraine include: 1) overcoming the protectionist policies of most countries of the world with regard to Ukrainian road transport enterprises; reducing tariff and non-tariff restrictions in this area; 2) improvement of the international integration of road transport companies to accumulate large financial resources, which is a prerequisite to introduce innovations; providing transportation services of higher quality at a lower cost; 3) promotion of antimonopoly policy in the international market of services of motor transport enterprises and stimulation of fair competition; 4) introduction of unification, standardization and system formation in the international motor transport services market in Ukraine.

Improving the competitiveness of transport enterprises during the accelerated development of the international logistics infrastructure is an urgent task of economics. Today, the competitiveness assessment itself should be conducted using up-to-date economic and mathematical methods and a personal computer. In addition, the methodology should be understandable for practitioners of the analytical departments of enterprises and be based on accessible software.

Domestic and foreign scientific literature focuses on marketing management methods, which allow taking into account the influence of hardly predictable market factors on the activity of the enterprise and, thus, increasing its survival rate in the intense market competition [1]. A company needs to study, analyze and assess these features, i.e. the strength of the influence of an unstable environment on the activities of the transport enterprise, the conditions of competition and hardly predictable behavior of competitors, first of all, in order to: 1) identify their competitive advantages and disadvantages vs. competitors; 2) determine the degree of its adaptation to the impact of external and internal factors of the market environment; 3) assess their competitiveness level; 4) develop complexes of organizational, economic, technical and technological measures aimed at its improvement; 5) develop various development scenarios for the market environment and effective competitive strategies for its development in this environment.

Today, when the competitiveness of an enterprise is a criterion of sustainability and survival of a transport enterprise during the accelerated development of the international logistics infrastructure, its analysis, evaluation and forecasting becomes objectively necessary, because in modern competitive struggle, with its large scale, changes and intensity, they who analyzes and fights for its competitive position win. In the market economy, only resilient enterprises can function, which flexibly adjust and use new mechanisms in management [2]. Quantitative assessment of the competitiveness level of a transport enterprise, as well as the development of measures to manage it becomes one of the important tasks.

Competitiveness can be assessed in the general and local aspects [3]. For transport enterprises, competitiveness in the general aspect is described as the satisfaction of consumers' demand and the ratio of performance indices with the parameters of a business system. The need to solve both economic and social problems of the territory where the company is located, determines the differentiation of indices by the same characteristic [4]. Activities of transport enterprises by the territorial authorities should be monitored mainly for solving social problems. Economic indices are indicators of the state of this system and information for making strategic decisions regarding stimulating the development of the logistics sector associated with specific innovation and investment programs [5].

The local aspect of competitiveness of the enterprise includes the need to assess the efficiency of resource use [6]. This task is set within transport enterprises and is a function of business structures. We propose a method for calculating the competitiveness coefficient, which belongs to the group of efficiency indicators of resource use and most fully reflects the business activity of the management of a transport enterprise. Other things being equal, 
business activity determines the development and effective use of the materials and technical facilities of an enterprise, as well as labor and financial resources [7].

It is proposed to consider the following elements as part of the competitiveness coefficient of a transport enterprise: 1) the range of the offered transportation services; 2) pricing policy; 3) advertising; 4) public relations; 5) sales system; 6) employee incentive system; 7) innovative activity of the enterprise.

We used the prioritization method for the quantitative determination of the competitiveness coefficient of the enterprise. The use of the expert assessment method is preconditioned by the fact that such organizational and economic problems are solved with the absent or incomplete necessary initial information. Using this method quite acceptable results can be obtained, which contributes to a noticeable improvement in the marketing activity of the enterprise [8].

A quantitative competitiveness assessment of the enterprise was obtained on the basis of expert information gathered by making specialists of the transport enterprises involved in the study to fill in specially designed questionnaires. The expert assessment procedure was based on the use of the method of pairwise comparison, in which all indices are compared in pairs, each subsequent assessment not being related to the previous one; all pairwise estimates form a pairing preference matrix which is further processed to obtain weight coefficients to the elements of the marketing complex.

The algorithm for assessing the competitiveness of transport enterprises includes: 1) determining the most significant elements that form competitiveness; 2) compilation of comparison systems for the surveyed enterprises by elements of the competitiveness coefficient; 3 ) determining the significance (weight) of elements that form competitiveness and their assessment; 4) assessment of the competitiveness level of a particular transport enterprise: 4.1) analysis of competitive factors; 4.2) determining the regression equation; 5) development of ways to improve competitiveness.

Our study covered 20 transport companies. Comparison systems for enterprises by the main factors of competitiveness were compiled as a result of a survey of 79 analysts and managers of enterprises in the region. Such comparison systems were used as the basis to plot square adjacency matrices which are further used to calculate the values of relative priorities for each competitive factor. Assessment of the primary competitive factors is given in Table 1.

Table 1. Assessment of the competitive factors.

\begin{tabular}{|l|l|}
\hline Competitive factors & Score \\
\hline 1. Range of offered transportation services & 0.190 \\
2. Pricing policy & 0.132 \\
3. Advertising & 0.105 \\
4. Public relations & 0.156 \\
5. Sales system & 0.116 \\
6. Employee incentive system & 0.159 \\
7. Innovative activity of the enterprise & 0.141 \\
\hline
\end{tabular}

To calculate the competitiveness coefficients, we have determined the significance of its elements, and then solved the problem of linear convolution of elements. Competitiveness scoring formed the basis for developing the competitiveness assessment methodology for the transport enterprises (Table 2). 
Table 2. Competitive scores of enterprises.

\begin{tabular}{|c|c|}
\hline Enterprise & Total competitive scores \\
\hline 1 & 0.052257 \\
\hline 2 & 0.057002 \\
\hline 3 & 0.072843 \\
\hline 4 & 0.061758 \\
\hline 5 & 0.070468 \\
\hline 6 & 0.037213 \\
\hline 7 & 0.046714 \\
\hline 8 & 0.036421 \\
\hline 9 & 0.048298 \\
\hline 10 & 0.068092 \\
\hline 11 & 0.053840 \\
\hline 12 & 0.041964 \\
\hline 13 & 0.062550 \\
\hline 14 & 0.038797 \\
\hline 15 & 0.041964 \\
\hline 16 & 0.041964 \\
\hline 17 & 0.041964 \\
\hline 18 & 0.041964 \\
\hline 19 & 0.041964 \\
\hline 20 & 0.041964 \\
\hline
\end{tabular}

We used the score assessment of such a quality factor as competitiveness of a transport enterprise (Figure 1) to calculate the operation performance using the correlation and regression analysis.

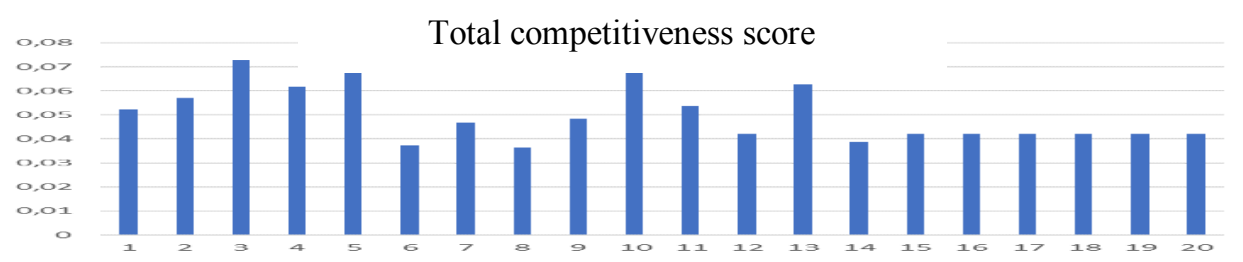

Fig. 1. Competitiveness assessment of transport enterprises in the region.

In our opinion, the advantage of the proposed methodology for determining the competitiveness of transport enterprises is that the equation for the amount of profit can be used to determine which specific competitive factor it is most significantly affected it. This will help make informed management decisions to improve the efficiency of economic activity in general, expand the information base of economic research, and improve the quality of analytical work.

We have also developed methodological tools for assessing the economic condition of a motor transport enterprise in the context of the accelerated development of the international transport infrastructure on the competitiveness of transport enterprises.

There is a relationship between the development of the international transport infrastructure and the competitiveness of Ukrainian road transport enterprises. We adjusted the competitiveness assessment methodology of enterprises on the basis of an assessment of their financial condition to the features of the transport market, and also related it to the international transport infrastructure. 
The developed methodology involves a regression analysis to identify the relationship between the level of development of the international transport infrastructure and the competitiveness of transport enterprises, reveals the degree of correlation of these indices, and uses them as the basis for recommendations in improvement of the competitiveness of transport enterprises.

In our method of economic analysis, the vector of all indices is the same. In other words, higher values of indices are evidence of a better economic state of the organization, while lower ones, on the contrary, indicate a worse economic state. The main advantages of the developed methodology include the complexity and multidimensionality of the analysis of the economic standing of the organization; comparability of data and the opportunity to compare different organizations, since standardized financial (accounting) reports are used for economic analysis; ability to identify the changes in of the development of the economic state of the analyzed organization; based on the results of the analysis, it is possible to make more efficient management decisions by the organization; the computational algorithm is flexible, provides the implementation of mathematical modeling of the economic situation of the organization; economic assessment provides the identification of deviations of production and business indices of the organization and allows to take appropriate measures to improve the competitiveness of the enterprise.

Assessment of the company's finance and production, planning the company's activities and forecasting its development is possible based on the results of the economic analysis.

Conducting a comprehensive economic analysis using the selected indices provides a description of the economic condition of the organization and allows planning a strategy based on the obtained results to improve the competitiveness of the transport enterprise.

\section{References}

1. Vasiutina I.O. State and Regions. Series: Economics and business, 5, 114-118 (2011)

2. Geleta I. V. Ekonomika organizatsii (predpriyatiya), Moscow: Magistr, 140 (2014)

3. Nikolaev M.V. Bulletin of Nizhny Novgorod University named after N. I. Lobachevsky. Series "Economics and Finance", 1 (7), 392-397, (2005)

4. Yankovoi O. (ed.) Konkurentospromozhnist pidpryiemstva: otsinka rivnia ta napriamy pidvyshchennia, Odessa: Atlant, 514 (2013)

5. Lifits I.M. Marketing, 3(88), 25-29, (2014)

6. Mansurov R.E. Marketing in Russia and abroad, 2 (52), 94-102, (2011)

7. Rodionova L.N., Khakimova O.G. Marketing in Russia and abroad, 1, 36-42, (2012)

8. Yatskovyi D. Visnyk sotsialno-ekonomichnykh doslidzhen, 4 (51), 183-188 (2013) 